\title{
THE URINARY EXCRETION OF COPPER AND ITS CONCENTRATION IN THE BLOOD OF NORMAL HUMAN ADULTS
}

\author{
BY \\ E. J. BUTLER AND G. E. NEWMAN \\ From the Departments of Biochemistry and Neurology, the Radcliffe Infirmary, Oxford
}

(RECEIVED FOR PUBLICATION MAY 12, 1955)

The values which have been published for the copper content of the fluids and tissues of normal people differ widely, and in many instances a critical examination of the analytical technique employed reveals serious defects which probably influenced the results. In our investigation of the copper status of cases of disseminated sclerosis and hepatolenticular degeneration it was therefore considered necessary to re-determine the urinary excretion of this metal and its concentration in the blood of a group of healthy adults using a more reliable technique, and the results are presented here.

The clinical importance of establishing accurate normal values has been emphasized in recent years by reports that patients with certain diseases have shown elevated concentrations of copper in their urine or blood when compared with control subjects. Thus a comparatively high urinary excretion of copper has been found in hepatolenticular degeneration (Mandelbrote, Stanier, Thompson, and Thruston, 1948 ; Cumings, 1951 ; Porter, 1951 ; Matthews, Milne, and Bell, 1952 ; Zimdahl, Hyman, and Cook, 1953 ; Bearn, 1953 ; Earl, 1954) and an elevation of the copper content of the blood has been observed in infectious diseases and anaemias (Cartwright, 1950, and authors cited), but it should be noted that many of the values for patients with these diseases lie within the limits of normal ranges reported by other authors.

\section{Subjects}

Investigations were carried out on 12 clinically healthy adults aged 18-32 years of whom three were non-pregnant women. With the exception of one, No. 2, who was a housewife, they were either laboratory workers or students, and so far as could be ascertained were unlikely to be ingesting an unusual amount of copper. They were all on a normal mixed diet.
The urinary zinc excretion and the zinc content of the blood of these people were also determined and the results will be presented in a separate communication.

\section{Method}

Special Precautions.-Strict precautions were taken to prevent contamination of the specimens by adventitious traces of copper during collection, storage, and analysis. The importance of these measures in work of this kind cannot be overemphasized, and they are described here since the descriptions of the technique used by other workers reveal in many cases that their precautions were inadequate. In all probability contamination is chiefly responsible for the wide variation in their results and the fact that they are generally considerably higher than those recorded here.

Only "pyrex" glassware was used, since fluids readily extract traces of copper (and other metals) from other brands. The magnitude of this contamination is illustrated by the values given in Table $I$ for the copper content of specimens of urine, blood, and

TABLE I

CONTAMINATION OF FLUIDS WITH COPPER BY NON"PYREX" BOTTLES

\begin{tabular}{|c|c|c|c|c|c|c|}
\hline \multirow{2}{*}{\multicolumn{4}{|c|}{ Type of Bottle }} & \multirow[b]{2}{*}{ Fluid } & \multicolumn{2}{|c|}{ Copper ( $\mu \mathrm{g}$. per $100 \mathrm{ml}$ ) } \\
\hline & & & & & Initially & $\begin{array}{l}\text { After } \\
\text { Contam- } \\
\text { ination }\end{array}$ \\
\hline \multicolumn{3}{|c|}{$\begin{array}{l}\text { Winchester } \\
\text { Amber, soft glass }\end{array}$} & $\begin{array}{l}\cdots \\
\cdots \\
\cdots\end{array}$ & \multirow{2}{*}{$\begin{array}{l}\text { Urine } \\
\text { Blood } \\
20 \% \text { ammonium } \\
\text { citrate solution }\end{array}$} & \multirow{3}{*}{$\begin{array}{c}2 \cdot 80 \\
0 \cdot 36 \\
77 \cdot 5 \\
0 \cdot 0 \\
0 \cdot 0\end{array}$} & \multirow{3}{*}{$\begin{array}{l}4 \cdot 10 \\
4 \cdot 22 \\
90 \cdot 0 \\
20 \cdot 2 \\
21 \cdot 8\end{array}$} \\
\hline ", & $"$ & $"$ & $\cdots$ & & & \\
\hline , & , & , & $\cdots$ & , $\quad$, & & \\
\hline
\end{tabular}

ammonium citrate solution before and after storage for 24 hours in bottles not of "pyrex" which had been specially cleaned as described below. It can be seen that contamination from this source may increase the copper content of a specimen of urine, for instance, to several times its original value. 
Ordinary laboratory standards of cleanliness are quite inadequate for trace element work. All glassware was put through a special cleaning procedure and was used only for this work. New glassware was first scrubbed thoroughly with "vim," rinsed well with tap water, and then washed with concentrated caustic soda solution (about $50 \%$ ), followed by concentrated nitric acid. It was then washed thoroughly with tap water and finally rinsed three times with distilled and metal-free water. The latter was obtained by redistilling distilled water in all-"pyrex" apparatus. After use, specimen bottles, syringes, digestion flasks, and pipettes for measuring samples were washed with nitric acid and rinsed with tap, distilled, and metal-free water as described above, while separating funnels and pipettes for reagents were rinsed with metal-free water before and after use.

All-steel needles specially made by Shrimpton and Fletcher Ltd. were found to be satisfactory for the collection of blood by venipuncture. The type of needle in common use for this purpose has a brass mount which is plated only on the outside, and it has not been generally realized that this seriously contaminates the blood with copper (and zinc) as it passes through. Experiments with a new, specially cleaned needle of this kind showed that this contamination may increase the copper content of a blood sample by as much as $15 \%$. It may be expected to be considerably greater from older needles which have been cleared in the usual manner with the brass wire provided. The needles were cleaned by boiling with dilute acetic acid (about $0.1 \mathrm{~N}$ ) and rinsing with metalfree water.

All apparatus was kept as free from dust as possible. Pipettes were stored in covered glass cylinders and were never allowed to touch the bench. The tops of bottles and standard flasks were covered with beakers, boiling tubes, or filter paper to prevent the accumulation of dust on the pouring surfaces. No rubber bungs or corks were used, since these are also sources of contamination.

AnalaR grade concentrated acids, ammonia, and solvents were purified by distillation in all-" pyrex" apparatus and solutions of AnalaR grade salts by extraction with dithizone solution. If this is omitted the amount of copper in the blank will be several times greater than that in the sample and so will seriously reduce the precision, range, and sensitivity of the analytical method. Metal-free water was used for making up all solutions.

Collection of Specimens.-In the past, most workers have collected 24-hourly specimens of urine for copper analysis, but some have worked with specimens collected over shorter periods, such as two hours (Mandelbrote et al., 1948), or at random (e.g., Earl, 1954). These smaller specimens have the obvious advantage of convenience, and to determine whether they are comparable the urinary copper excretion of three subjects was followed throughout 24-hour periods. The results given in Table II show that it undergoes a considerable diurnal variation. In view of this finding 24-hourly specimens were collected from the remaining subjects for copper analysis.

The urine was collected directly into wide-necked, 2- or 3-litre "pyrex" bottles, a funnel being provided for the women. The bottles were kept stoppered and the tops covered with filter paper when they were not in actual use during the collection period.

Blood was taken with an all-steel needle attached $\unrhd$ to an ungreased "pyrex" syringe and was expelled क into a "pyrex" tube provided with a stopper and $\overrightarrow{0}$ containing purified ammonium citrate as an anticoagulant. All specimens were collected between $10 \overrightarrow{\vec{\omega}}$ and 10.30 a.m., since the results of Nielsen (1944) had $\stackrel{\omega}{\omega}$ indicated that there is a diurnal variation in the copper content of serum. This has since been confirmed for serum by Munch-Petersen (1950b) and for plasma and red cells by Lahey, Gubler, Cartwright, and Wintrobe (1953). Thus in order to obtain comparable results the specimens must be collected at approximately the same time of the day.

Analytical Procedure.-The same sample $(20 \mathrm{ml}$. of urine or $1 \mathrm{ml}$. of blood) was used for the absorptiometric determination of both copper and zinc with $\vec{\theta}$ dithizone by improved procedures which were devised fु for these studies (Butler, 1952). It was first "wet" ashed with a mixture of sulphuric, nitric, and perchloric acids, the residue dissolved in ammoniacal citrate solution and the $p \mathrm{H}$ adjusted to about 8.5 응 exactly as described in a previous publication on the determination of lead (Irving and Butler, 1953). After $\mathbb{D}$ making up the volume of this solution to $50 \mathrm{ml}$. with $\stackrel{2}{\vec{F}}$ metal-free water, a sample was removed for the determination of zinc $(5 \mathrm{ml}$. for urine and $10 \mathrm{ml}$. for 3 blood) and the remainder was transferred to a $60-\mathrm{ml}$. separating funnel for the determination of copper as described below.

Then $4 \mathrm{ml}$. of $2 \mathrm{~N}$ sulphuric acid was added to? reduce the $p \mathrm{H}$ to about 5 and the copper was isolated by shaking with successive $2 \mathrm{ml}$. portions of a solution. of dithizone in carbon tetrachloride $(20 \mathrm{mg}$. per litre) until the green colour of the reagent was unchanged. The shaking was performed mechanically for 10-음 minute periods at a rate of 200 shakes per minute. $\rightarrow$ The extracts were pooled in a $20-\mathrm{ml}$. separating funnelo and then shaken by hand with $5 \mathrm{ml}$. of a $0.007 \%$. solution of A.R. potassium permanganate in $0.1 \mathrm{~N} /$ sulphuric acid. This oxidized the copper dithizonate $N$ and the excess dithizone, and so permitted the transference of copper to the aqueous phase.

After carefully removing the organic phase, $5 \mathrm{ml}$ of a solution containing $5 \mathrm{~g}$. of sodium acetate ando $10 \mathrm{~g}$. of potassium iodide per litre and saturated with sulphur dioxide was added and the solutions? thoroughly mixed. The $p \mathrm{H}$ of the solution was now about 1.5 and copper was re-extracted from it byo shaking mechanically for 10 minutes with exactly $2 \mathrm{ml} . \mathbb{\mathrm { D }}$ of the dithizone solution. Finally the absorbancy of this extract was measured in a covered $1-\mathrm{cm}$. microcell with a Hilger Spekker absorptiometer (H.760) using a tungsten filament lamp, Ilford No. 607 oranges 
filters and water in the reference cell, having previously dried the stem of the separating funnel with a roll of filter paper and plugged it with a small piece of purified cotton-wool to prevent the transference of droplets of the aqueous phase to the optical cell.

The difference between this absorbancy value and that for the blank which had been taken through the entire procedure was then calculated. Division of this figure by the calibration factor obtained from a standard curve gave the amount of copper in the original solution of the digest. The standard curve was determined by mixing $x \mathrm{ml}$. of a standard solution of A.R. copper sulphate pentahydrate in $0.1 \mathrm{~N}$ sulphuric acid containing $1 \mu \mathrm{g}$. of copper per $\mathrm{ml}$., $5-x \mathrm{ml}$. of $0.1 \mathrm{~N}$ sulphuric acid, and $5 \mathrm{ml}$. of the acetate-iodide-sulphurous acid solution, and then extracting with $2 \mathrm{ml}$. of the dithizone solution and measuring the absorbancy of the extracts exactly as in the final stage of the procedure. The curve was linear for amounts of copper up to $1.7 \mu \mathrm{g}$., and over this range $1 \mu \mathrm{g}$. produced a change in absorbancy of 0.225 .

The final absorptiometric procedure was suggested by Irving, Risdon, and Andrew (1949), and among its advantages over others which have been employed are that it does not require a pure standard solution of dithizone, which is notorious for its instability in solution, a correction is automatically made for the amount of copper in the blank, and calibration is simple.

Satisfactory recoveries of 0.3 to $1.2 \mu \mathrm{g}$. of added copper were obtained from samples of biological material, and no interference could be detected from much greater amounts of other metals than are likely to be encountered in such samples.

Sodium diethyldithiocarbamate has been more widely used than dithizone for the estimation of copper in biological materials, but we preferred the latter on account of its greater sensitivity and the fact that interference from all other metals likely to be present could be more readily eliminated. The amount of iron, for example, which can be tolerated by the diethyldithiocarbamate methods which were available at the beginning of our investigations (1949) is strictly limited, and, unknown to the analyst, may be exceeded in certain samples, which in consequence will appear to contain more copper than is actually present. The errors arising from this interference may be particularly serious in studies of copper deficiency in mammals which causes the accumulation of abnormally large amounts of iron in the tissues by retarding its utilization. For instance, the concentration of iron in the liver of a copper-deficient sheep may be several hundred times greater than the normal value (Marston, 1950).

\section{Results and Discussion}

Urinary Copper Excretion.-The data presented in Table II show that there is a considerable diurnal variation in urinary copper excretion both in rate ( $\mu \mathrm{g}$. per 4 hours) and concentration $(\mu \mathrm{g}$. per
TABLE II

DIURNAL VARIATION IN URINARY COPPER EXCRETION

\begin{tabular}{|c|c|c|c|c|}
\hline $\begin{array}{l}\text { Subject } \\
\text { No. }\end{array}$ & $\begin{array}{l}8 \text { a.m. to } \\
12 \text { Noon }\end{array}$ & $\begin{array}{l}12 \text { Noon } \\
\text { to } 4 \text { p.m. }\end{array}$ & $\begin{array}{l}4 \text { p.m. to } \\
8 \text { p.m. }\end{array}$ & $\begin{array}{l}8 \text { p.m. to } \\
8 \text { a.m. }\end{array}$ \\
\hline $\begin{array}{l}1 \\
2 \\
3\end{array}$ & $\begin{array}{l}2.54 \\
3.98 \\
2.77\end{array}$ & $\begin{array}{c}\text { pper Excre } \\
5.01 \\
7.01 \\
6.45\end{array}$ & $\begin{array}{c}(\mu \mathrm{g} \text {. per } 4 \mathrm{~F} \\
3 \cdot 29 \\
4 \cdot 60 \\
4 \cdot 89\end{array}$ & $\begin{array}{l}2.33 \\
4.68 \\
0.59\end{array}$ \\
\hline $\begin{array}{l}1 \\
2 \\
3\end{array}$ & $\begin{array}{l}{ }^{\text {Cop }} \\
3.43 \\
3.18 \\
2.47\end{array}$ & $\begin{array}{c}\text { Excreted } \\
2.61 \\
3.89 \\
2.35\end{array}$ & $\begin{array}{c}\text { per } 100 \mathrm{ml} \\
1.89 \\
2.12 \\
1.06\end{array}$ & $\begin{array}{r}\text { rine) } \\
1.49 \\
3.02 \\
0.19\end{array}$ \\
\hline
\end{tabular}

$100 \mathrm{ml}$. urine). In this respect it resembles that of other trace metals, viz., lead (Webster, 1941) and zinc (Drinker, Fehnel, and Marsh, 1927; Butler and Newman, in preparation) and also macro-constituents such as urea and phosphate. The rate of copper excretion of the three subjects varied in a regular manner over the first three four-hour periods and was in each case greatest during the second period, i.e., from 12 noon to 4 p.m. This variation is roughly parallel to the change in the copper content of the plasma and erythrocytes recently reported by Lahey et al. (1953). The concentration of copper in the urine showed no such regularity in its fluctuation. These subjects were all leading normal lives and took a meal at the beginning of each period.

The percentage of the 24-hourly copper excretion which was excreted in a given period was most constant for the first period, i.e., from 8 a.m. to 12 noon, when it varied from $13.5 \%$ to $17.4 \%$. If more extensive investigations confirm this finding, specimens collected over this period would yield comparable results, but at the moment the effect of the diurnal variations can only be eliminated with certainty by collecting the urine over one or more complete 24-hour periods.

It can be seen from Table III that the values previously published for the urinary copper excretion of healthy adult Europeans and Americans

TABLE III

VALUES PREVIOUSLY REPORTED FOR URINARY COPPER EXCRETION OF NORMAL ADULTS COMPARED WITH PRESENT VALUES

\begin{tabular}{|c|c|c|c|c|c|}
\hline \multirow[t]{2}{*}{ Author } & \multirow{2}{*}{$\begin{array}{l}\text { No. of } \\
\text { Sub- } \\
\text { jects }\end{array}$} & \multicolumn{2}{|c|}{$\begin{array}{c}\text { Cu Excreted } \\
(\mu \mathrm{g} . \text { per } \\
24 \mathrm{Hr} .)\end{array}$} & \multicolumn{2}{|c|}{$\begin{array}{c}\text { Cu Excreted } \\
\text { ( } \mu \mathrm{g} . \text { per 1. of } \\
24 \text {-hr. Specimen })\end{array}$} \\
\hline & & Range & Mean & Range & Mean \\
\hline $\begin{array}{l}\text { Tompsett (1934a) } \\
\text { Leverton (1939) } \\
\text { van Ravesteyn (1944) } \\
\text { Holt and Scoular (1948) } \\
\text { Porter (1951) } \\
\text { Bearn and Kunkel (1952) } \\
\text { Matthews et al. (1952). } \\
\text { Butler and Newman (this }\end{array}$ & $\begin{array}{r}6 \\
24 \\
4 \\
17 \\
11 \\
17\end{array}$ & $\begin{array}{c}210-380^{*} \\
25-320 \\
0-100 \\
20-675^{*} \\
0-14 \cdot 7 \\
0-25 \\
10-68\end{array}$ & $\begin{array}{r}300 \\
200 \\
34 \\
209 \\
- \\
\overline{35}\end{array}$ & $\begin{array}{l}\overline{\overline{1}} \\
0-\overline{125} \\
0-\overline{20} \\
\overline{-}\end{array}$ & $\begin{array}{l}\bar{z} \\
\bar{z} \\
-\end{array}$ \\
\hline $\begin{array}{lll}\text { paper) } & \ldots & \ldots\end{array}$ & 12 & $3 \cdot 9-29 \cdot 6$ & $18 \cdot 0$ & $2 \cdot 7-29 \cdot 9$ & $15 \cdot 4$ \\
\hline
\end{tabular}

* Mean values for several specimens from each subject. 
over 24-hour periods differ considerably and lie within the wide range of 0 to $675 \mu \mathrm{g}$. per 24 hours.

The results of Rabinowitch (1933) published under the heading "The Copper Content of the Urine of Normal Individuals" extend over an even greater range, viz., $0-700 \mu \mathrm{g}$. per 24 hours (mean $>285 \mu \mathrm{g}$.), and have frequently been quoted as normal values. However, they cannot be classed as such, since, according to the text, they were obtained on hospital patients selected at random, and they are omitted from Table III for this reason, as are those of Munch-Petersen (1950a), which range from 9 to $80 \mu \mathrm{g}$. per 24 hours.

The values recorded here (see Table IV) vary from 3.9 to $29.6 \mu \mathrm{g}$. per 24 hours, about a mean value of 18.0 , and are thus much lower than many previously reported. They are in good agreement with those recently published by Porter (1951) and Bearn and Kunkel (1952), and with the conclusion reached by Leverton and Binkley (1944) that the urinary loss of copper approximates to $20 \mu \mathrm{g}$. per day. Excretions of this order of magnitude were probably encountered by Ohlson and Daum (1935), who were amazed to find that their analytical method was not sufficiently sensitive to estimate them in view of the results of Rabinowitch.

TABLE IV

VALUES FOR THE URINARY EXCRETION OF COPPER AND ITS CONCENTRATION IN THE BLOOD OF NORMAL

\begin{tabular}{|c|c|c|c|c|}
\hline \multirow[b]{2}{*}{$\begin{array}{c}\text { Subject } \\
\text { No. }\end{array}$} & \multirow[b]{2}{*}{ Sex } & \multicolumn{2}{|c|}{ Urinary Excretion } & \multirow{2}{*}{$\begin{array}{c}\mathrm{Cu} \\
\text { Concentration } \\
(\mu \mathrm{g} . \mathrm{per} \\
100 \mathrm{ml} .) \text { in } \\
\text { Whole Blood }\end{array}$} \\
\hline & & $\begin{array}{c}\mathrm{Cu} \\
(\mu \mathrm{g} . \mathrm{per} \\
24 \mathrm{Hr} .)\end{array}$ & $\begin{array}{l}\mathrm{Cu}(\mu \mathrm{g} . \text { per } 1 . \\
\text { of 24-hr. } \\
\text { Specimen) }\end{array}$ & \\
\hline $\begin{array}{r}1 \\
2 \\
3 \\
4 \\
5 \\
6 \\
7 \\
8 \\
9 \\
10 \\
11 \\
12\end{array}$ & $\begin{array}{l}\mathbf{M} \\
\mathbf{F} \\
\mathbf{M} \\
\mathbf{M} \\
\mathbf{M} \\
\mathbf{M} \\
\mathbf{F} \\
\mathbf{M} \\
\mathbf{M} \\
\mathbf{M} \\
\mathbf{M} \\
\mathbf{F}\end{array}$ & $\begin{array}{r}17.8 \\
29.6 \\
15.9 \\
14.3 \\
3.9 \\
16.6 \\
18.4 \\
26.8 \\
17.3 \\
27.7 \\
16 \cdot 6 \\
11.1\end{array}$ & $\begin{array}{r}19 \cdot 6 \\
29.9 \\
9 \cdot 1 \\
12.5 \\
2.7 \\
21.0 \\
12.3 \\
13 \cdot 3 \\
11.5 \\
28.0 \\
12.3 \\
13.1\end{array}$ & $\begin{array}{l}74 \cdot 6 \\
77 \cdot 5 \\
72.9 \\
73 \cdot 3 \\
76 \cdot 1 \\
80 \cdot 7 \\
84.9 \\
77.8 \\
82.7 \\
66 \cdot 2 \\
83.5 \\
69.0\end{array}$ \\
\hline$\overline{\text { Mean }}$ & & $18 \cdot 0$ & $15 \cdot 4$ & $76 \cdot 6$ \\
\hline \multicolumn{2}{|c|}{ Standard deviation } & $\pm 7 \cdot 23$ & $\pm 7 \cdot 81$ & $\pm 5 \cdot 78$ \\
\hline
\end{tabular}

Thus in the light of this work the statement made in a review of the subject by Cartwright (1950) to the effect that the normal excretion of copper through the kidneys in adults is about $250 \mu \mathrm{g}$. per 24 hours is grossly inaccurate, and it is probable that the true excretion rarely exceeds one tenth of this value. The high results of earlier workers may be attributed to contamination of the specimen with copper from extraneous sources such as the atmosphere and glassware, which, as was shown above, can be considerable unless special precautions are taken.

Copper in Blood.-The values previously published for the concentration of copper in the blood of healthy adult Europeans and Americans range from 66 to $229 \mu \mathrm{g}$. per $100 \mathrm{ml}$. (Table V). Those recorded here (Table IV) vary from 66.2 to $84.9 \mu \mathrm{g}$. per $100 \mathrm{ml}$., about a mean value of 76.6. They are much lower than those reported by the majority of previous workers and do not support the conclusion of Cumings (1951) that "normal figures for blood cзpper can be considered to be up to about $120-150 \mu \mathrm{g}$. per $100 \mathrm{ml}$." io Our values show best agreement with those of ? Holmberg (1941) and Lahey et al. (1953).

TABLE V

VALUES PREVIOUSLY REPORTED FOR CONCENTRATION OF COPPER IN THE BLOOD OF NORMAL ADULTS COMPARED WITH PRESENT VALUES

\begin{tabular}{|c|c|c|c|}
\hline \multirow[t]{2}{*}{ Author } & \multirow{2}{*}{$\begin{array}{c}\text { No. of } \\
\text { Subjects }\end{array}$} & \multicolumn{2}{|c|}{$\begin{array}{l}\text { Cu Concentration ( } \mu \mathrm{g} . \\
\text { per } 100 \mathrm{ml} .) \text { in } \\
\text { Whole Blood }\end{array}$} \\
\hline & & Range & Mean \\
\hline 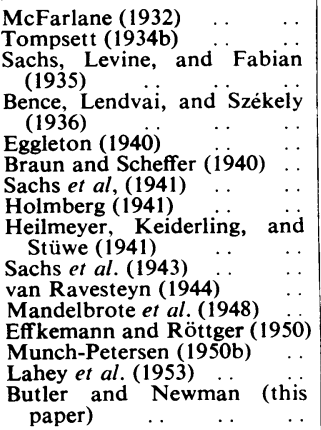 & $\begin{array}{r}8 \\
20 \\
3 \\
19 \\
10 \\
31 \\
63\end{array}$ & $\begin{array}{c}170,185 \\
185-229 \\
110-160 \\
74-141^{*} \\
156-228 * \dagger \\
119-157 \\
115-140 \\
66-122 \\
87-147 \\
90-121 \\
95-142 \\
100-225 \\
79-126 \\
77-135 \\
69-117 \\
66 \cdot 2-84 \cdot 9\end{array}$ & $\begin{array}{l}104^{*} \\
165^{* \dagger} \\
140 \\
125 \\
96.6\end{array}$ \\
\hline
\end{tabular}

* These values were calculated from the original values assuming the specific gravity of blood was equal to 1.06 .

t Indicates that several samples from each subject were analysed.

While some of the difference between the two sets of results may be due to dietary factors and $N$ the collection of blood at different times of the day, it is probable that the greater part of it is accounted for by contamination of the samples by $\omega$ glassware and syringe needles, and by interference? from iron in the determination of copper byce sodium diethyldithiocarbamate in the earlier work.

Holmberg (1941), whose values are of the same? magnitude as ours, stated that he used stainless steel needles polished on the inside which gave no용 measurable amount of copper, but the other authors, with the exception of Sachs, Levine, $\stackrel{\mathbb{Q}}{\varrho}$ Andersen, and Schmit (1941), give no details of the needles they used, and it is probable that they 
were of the type in general use which has a brass mount and seriously contaminates the blood sample. Sachs et al. used needles made of platinum, which also produces high results (Bailey and McHargue, 1945). The use of these brass-mounted needles for collecting blood for copper analysis has also been condemned by Marston and Lee (1948) and by Vikbladh (1950). Marston and Lee concluded that contamination from this source has with little doubt complicated at least some of the analytical findings on ruminants in the literature, and there appears to be some justification for extending this conclusion to include humans.

\section{Summary}

It was found that there is a considerable diurnal variation in urinary copper excretion both in rate and concentration.

The analysis of 24-hour specimens of urine from 12 healthy adults gave excretion values from 3.9 to $29.6 \mu \mathrm{g}$. copper per 24 hours (mean 18.0) and from 2.9 to $29.9 \mu \mathrm{g}$. copper per 1 . (mean 15.4).

The copper content of the blood of these people ranged from 66.2 to $84.9 \mu \mathrm{g}$. per $100 \mathrm{ml}$., about a mean value of 76.6 .

Strict precautions were taken to ensure that there was no significant contamination of specimens by traces of copper from extraneous sources such as the atmosphere, glassware, and syringe needles. Insufficient attention to these measures is probably chiefly responsible for the high and variable results reported by the majority of previous workers.

We are indebted to Mr. J. R. P. O'Brien for providing laboratory facilities and for his valuable advice; to Dr. W. Ritchie Russell for his help and encouragement ; to our normal subjects for their cooperation; to Shrimpton and Fletcher Ltd., Redditch, for specially making the all-steel syringe needles; and to the Medical Research Council for grants for wholetime work.

\section{REFERENCES}

Bailey, L. F., and McHargue, J. S. (1945). Plant Physiol., $20,79$. Bearn, A. G. (1953). Amer. J. Med., 15, 442.

and Kunkel, H. G. (1952). J. clin. Invest., 31, 616.

Bence, J., Lendvai, J., and Székely, J. (1936). Z, klin. Med., 130, 299.

Braun, L., and Scheffer, L. (1940). Biochem. Z., 304, 397.

Butler, E. J. (1952). Studies in the Determination and Biological Significance of Traces of Metals. Thesis for D.Phil. degree, University of Oxford.

Cartwright, G. E. (1950). In Copper Metabolism, pp. 274-310. Ed. McElroy, W. D., and Glass, B. Johns Hopkins Press, Baltimore.

Cumings, J. N. (1951). Brain, 74, 10.

Drinker, K. R., Fehnel, J. W., and Marsh, M. (1927). J. biol. Chem., 72, 375.

Earl, C. J. (1954). Lancet, 1, 234.

Effkemann, G., and Röttger, H. (1950). Klin. Wschr., 28, 216.

Eggleton, W. G. E. (1940). Chin. J. Physiol., 15, 33.

Heilmeyer, L., Keiderling, W., and Stüwe, G. (1941). Quoted by Cartwright (1950).

Holmberg, C. G. (1941). Acta physiol. scand., 2, 71.

Irving, H. M., and Butler, E. J. (1953). Analyst, 78, 571

Irving, Risdon, E. J., and Andrew, G. (1949). J. chem. Soc., p. 537.

Lahey, M. E., Gubler, C. J., Cartwright, G. E., and Wintrobe, M. M. (1953). J. clin. Invest., 32, 322.

Leverton, R. M. (1939). J. Nutr., 17, Suppl. p. 17.

and Binkley, E. S. (1944). Ibid., $27,43$.

McFarlane, W. D. (1932). Biochem. J., 26, 1022.

Mandelbrote, B. M., Stanier, M. W., Thompson, R. H. S., and Thruston, M. N. (1948). Brain, 71, 212.

Marston, H. R. (1950). In Copper Metabolism, p. 237. Ed. McElroy, W. D., and Glass, B. Johns Hopkins Press, Baltimore.

and Lee, H. J. (1948). J. agric. Sci., 38, 229.

Matthews, W. B., Milne, M. D., and Bell, M. (1952). Quart. J. Med., n.s. $21,425$.

Munch-Petersen, S. (1950a). Scand. J. clin. Lab. Invest., 2, 337.

- (1950b). Ibid., 2, 53 .

Nielsen, A. L. (1944). Acta med. scand., 118, 87.

Ohlson, M. A., and Daum, K. (1935). J. Nutr., 9, 75.

Porter, H. (1951). Arch. Biochem. Biophys., 31, 262.

Rabinowitch, I. M. (1933). J. biol. Chem., 100, 479.

Ravesteyn, A. H. van (1944). Acta med. scand., 118, 163.

Sachs, A., Levine, V. E., and Fabian, A. A. (1935). Arch. intern. Med., 55, 227. Med., 26,734. A. C., and Schmit, A. (1941). J. Lab. clin. 489 . Hill, F. C., and Hughes, R. (1943). Arch. intern. Med., 71,

Tompsett, S. L. (1934a). Biochem. J., 28, 2088.

(1934b). Ibid., 28, 1544.

Vikbladh, I. (1950). Scand. J. clin. Lab. Invest., 2, 143.

Webster, S. H. (1941). Publ. Hlth Rep., Wash., 56, 1834.

Zimdahl, W. T., Hyman, I., and Cook, E. D. (1953). Neurology, 3, 569. 